\title{
Fenton Process Coupled to Ultrasound and UV Light Irradiation for the Oxidation of a Model Pollutant
}

\author{
Karen E. Barrera-Salgado, ${ }^{1}$ Gabriela Ramírez-Robledo, ${ }^{1}$ \\ Alberto Álvarez-Gallegos, ${ }^{2}$ Carlos A. Pineda-Arellano, ${ }^{3}$ Fernando Z. Sierra-Espinosa, ${ }^{2}$ \\ J. Alfredo Hernández-Pérez, ${ }^{2}$ and Susana Silva-Martínez ${ }^{2}$ \\ ${ }^{1}$ Posgrado en Ingeniería y Ciencias Aplicadas, Universidad Autónoma del Estado de Morelos, Avenida Universidad 1001, \\ Colonia Chamilpa, 62209 Cuernavaca, MOR, Mexico \\ ${ }^{2}$ Centro de Investigación en Ingeniería y Ciencias Aplicadas, Universidad Autónoma del Estado de Morelos, \\ Avenida Universidad 1001, Colonia Chamilpa, 62209 Cuernavaca, MOR, Mexico \\ ${ }^{3}$ Centro de Investigaciones en Óptica, A.C., CONACYT, Prolongación Constitución 607, Fraccionamiento Reserva Loma Bonita, \\ 20200 Aguascalientes, AGS, Mexico
}

Correspondence should be addressed to Susana Silva-Martínez; ssilva@uaem.mx

Received 8 February 2016; Revised 27 March 2016; Accepted 5 April 2016

Academic Editor: Davide Vione

Copyright (C) 2016 Karen E. Barrera-Salgado et al. This is an open access article distributed under the Creative Commons Attribution License, which permits unrestricted use, distribution, and reproduction in any medium, provided the original work is properly cited.

\begin{abstract}
The Fenton process coupled to photosonolysis (UV light and Us), using $\mathrm{Fe}_{2} \mathrm{O}_{3}$ catalyst supported on $\mathrm{Al}_{2} \mathrm{O}_{3}$, was used to oxidize a model pollutant like acid green 50 textile dye (AG50). Dye degradation was followed by AG50 concentration decay analyses. It was observed that parameters like iron content on a fixed amount of catalyst supporting material, catalyst annealing temperature, initial dye concentration, and the solution $\mathrm{pH}$ influence the overall treatment efficiency. High removal efficiencies of the model pollutant are achieved. The stability and reusability tests of the $\mathrm{Fe}_{2} \mathrm{O}_{3}$ catalyst show that the catalyst can be used up to three cycles achieving high discoloration. Thus, this catalyst is highly efficient for the degradation of AG50 in the Fenton process.
\end{abstract}

\section{Introduction}

There is an increasing concern regarding the detrimental effects of textile dyes on the environment because they can be potentially toxic, carcinogenic, and mutagenic [1]. Degradation and mineralization of textile effluents have become of increasing importance in recent years due to the more stringent environmental legislation. Currently, advanced oxidation processes represent a feasible technology since these methods are efficient for the treatment of industrial dyes and organic pollutants in the textile industry wastewater [2]. The Fenton process is amongst these processes and it is a viable option because of its high oxidizing power and its cost/benefit ratio [3]. The Fenton process is a homogeneous advanced oxidation process (AOP) involving the reaction of $\mathrm{Fe}(\mathrm{II})$ with hydrogen peroxide, generating hydroxyl radicals. This catalytic reaction is propagated in chain reactions in which the hydroxyl radicals will subsequently attack the organic compounds present in solution [4]. Nevertheless, the homogeneous Fenton process is limited to acidic $\mathrm{pH}$ solutions $(2.5<\mathrm{pH}<4.0)$ [5] generating iron sludge in the neutralization step which requires proper disposal [6]. The heterogeneous Fenton process involves the use of solid Fenton catalyst that would minimize such problems. Several catalyst supporting materials have been synthetized like pillared clay-based catalysts [7], iron-oxide mineral catalysts [8,9], $\mathrm{Fe}(\mathrm{II}) \mathrm{Fe}(\mathrm{III})-$ layered double hydroxides [10], iron-activated carbon catalyst $[11,12]$, and $\mathrm{Fe}(\mathrm{II}) /(\mathrm{III})-\mathrm{Al}_{2} \mathrm{O}_{3}[13-15]$, among others. Organic pollutants such as textile dyes $[7,9,10,13,16-$ 18], phenol and related compounds [11, 12, 19, 20], and lignin [21] have been oxidized by the heterogeneous Fenton process.

The Fenton process has also been combined with other AOP such as ultrasound [22, 23], UV light [20, 23, 24], UV light and ultrasound [25], $\mathrm{TiO}_{2}$ photocatalysis [26], and ozone [27]. Basturk and Karatas [22] observed that the 
<smiles>CN(C)c1ccc(C(=C2C=CC(=[N+](C)C)C=C2)c2c(O)c(S(=O)(=O)O[NH3+])cc3cc(S(=O)(=O)[O-])ccc23)cc1</smiles>

Chemical formula (molecular weight): $\mathrm{C}_{27} \mathrm{H}_{25} \mathrm{~N}_{2} \mathrm{NaO}_{7} \mathrm{~S}_{2}$ (576.61 $\mathrm{g} \mathrm{mol}^{-1}$ )

Scheme 1: Molecular structure of the acid green 50 dye.

highest decolorization of an anthraquinone dye was achieved by the sono-Fenton process because of the production of some oxidizing agents as a result of sonication. Ultrasound coupling with the heterogeneous Fenton-like reagent over copper oxide was investigated for the abatement of $p$ chlorophenol in aqueous solutions; synergistic effects in the combination of ultrasound $-\mathrm{H}_{2} \mathrm{O}_{2}$-catalyst were observed [20]. It was reported that combining the Fenton process with $\mathrm{TiO}_{2}$ photocatalysis [26] and with ozone [27] gave higher removal efficiencies of the organic pollutant than that obtained by the Fenton process alone.

The aim of this work is to study the degradation of acid green 50 industrial textile dye by Fenton process, using $\mathrm{Fe}_{2} \mathrm{O}_{3}$ catalyst supported on $\mathrm{Al}_{2} \mathrm{O}_{3}$, in tandem with ultrasound and UV light irradiation to evaluate the possible beneficial effects on the use of coupled systems. The influences of iron catalyst content, initial dye concentration, and $\mathrm{pH}$ of the solution are studied to assess the overall treatment efficiency of the degradation processes in a batch recirculation system. The catalyst stability is also studied.

AG50 is a triarylmethane anionic dye (derivative of triphenyl methane). Its molecular structure and chemical formula are depicted in Scheme 1.

One hundred and forty-two electrons need to be removed from the AG50 dye to achieve conversion into carbon dioxide and mineral acids (mineralization) in the Fenton reaction. This is by considering the notion that the nitrogen atom gets converted into nitrates. Thus, the stoichiometry of AG50 reacting with $\mathrm{H}_{2} \mathrm{O}_{2}$ is given by

$$
\begin{aligned}
& \mathrm{C}_{27} \mathrm{H}_{25} \mathrm{~N}_{2} \mathrm{NaO}_{7} \mathrm{~S}_{2}+71 \mathrm{H}_{2} \mathrm{O}_{2} \\
& \longrightarrow 27 \mathrm{CO}_{2}+2 \mathrm{H}_{2} \mathrm{SO}_{4}+\mathrm{NaNO}_{3}+\mathrm{HNO}_{3} \\
&+81 \mathrm{H}_{2} \mathrm{O}
\end{aligned}
$$

The mechanism of hydrogen peroxide activation by iron ions in the homogeneous Fenton process mainly involves the generation of $\mathrm{OH}^{\circ}$ radicals $[4,28]$ :

$$
\mathrm{Fe}^{2+}+\mathrm{H}_{2} \mathrm{O}_{2} \longrightarrow \mathrm{Fe}^{3+}+\mathrm{OH}^{-}+\mathrm{OH}^{\bullet}
$$

Reaction (2) is followed by the subsequent chain reactions

$$
\begin{gathered}
\mathrm{Fe}^{2+}+\mathrm{OH}^{\bullet} \longrightarrow \mathrm{Fe}^{3+}+\mathrm{OH}^{-} \\
\mathrm{OH}^{\bullet}+\mathrm{H}_{2} \mathrm{O}_{2} \longrightarrow \mathrm{H}_{2} \mathrm{O}+\mathrm{OOH}^{\bullet} \\
\mathrm{Fe}^{3+}+\mathrm{H}_{2} \mathrm{O}_{2} \longrightarrow \mathrm{Fe}^{2+}+\mathrm{H}^{+}+\mathrm{OOH}^{\bullet} \\
\mathrm{Fe}^{3+}+\mathrm{R}^{\bullet} \longrightarrow \mathrm{Fe}^{2+}+\mathrm{R}^{+} \\
\mathrm{Fe}^{3+}+\mathrm{OOH}^{\bullet} \longrightarrow \mathrm{Fe}^{2+}+\mathrm{H}^{+}+\mathrm{O}_{2}
\end{gathered}
$$

Nevertheless, the formation of a highly reactive iron-oxo complex (the ferryl ion, $\mathrm{Fe}^{\mathrm{IV}} \mathrm{O}^{2+}$ ) as the oxidative intermediate in the homogeneous Fenton reaction has also been proposed [29]:

$$
\mathrm{Fe}^{2+}+\mathrm{H}_{2} \mathrm{O}_{2} \longrightarrow \mathrm{Fe}^{\mathrm{IV}} \mathrm{O}^{2+}
$$

Thus, a controversy still exists on whether the chemical mechanism involves radical or ferryl ion generation as the active intermediate species. Then, the chemical pathway in the heterogeneous Fenton reaction is less understood. It has been suggested to be through either the adsorption of the $\mathrm{H}_{2} \mathrm{O}_{2}$ molecule or the adsorption of the organic compounds onto $\equiv \mathrm{Fe} \mathrm{III}^{\mathrm{II}}$ sites [30]. Hence, $\mathrm{Fe}^{3+}$ is reduced with the generation of less oxidative $\mathrm{OOH}^{*}$ radicals, followed by $\mathrm{Fe}^{3+}$ regeneration with the formation of $\mathrm{OH}^{*}$ radicals $[7,8,12,30]$ :

$$
\begin{aligned}
& \equiv \mathrm{Fe}^{3+}+\mathrm{H}_{2} \mathrm{O}_{2} \longrightarrow \equiv \mathrm{Fe}^{2+}+\mathrm{OOH}^{\bullet}+\mathrm{H}^{+} \\
& \equiv \mathrm{Fe}^{2+}+\mathrm{H}_{2} \mathrm{O}_{2} \longrightarrow \equiv \mathrm{Fe}^{3+}+\mathrm{OH}^{-}+\mathrm{OH}^{\bullet}
\end{aligned}
$$

where $\equiv$ represents the surface of the catalyst. Also, many other radical reactions can occur similar to those in the homogeneous Fenton reaction [4]. The $\mathrm{OH}^{*}$ radical production in the Fenton reaction increases upon UV light illumination [31], reaction (11), and with ultrasound, denoted by ))) [22], reactions (12)-(17):

$$
\begin{gathered}
\mathrm{Fe}^{\mathrm{III}}(\mathrm{OH})^{2+} \stackrel{\mathrm{h} v}{\longrightarrow} \mathrm{Fe}^{2+}+\mathrm{OH}^{\bullet} \\
\left.\left.\left.\mathrm{H}_{2} \mathrm{O}+\right)\right)\right) \longrightarrow \mathrm{OH}^{\bullet}+\mathrm{H}^{\bullet}
\end{gathered}
$$

with the subsequent chemical reactions

$$
\begin{aligned}
\mathrm{OH}^{\bullet}+\mathrm{H}^{\bullet} & \longrightarrow \mathrm{H}_{2} \mathrm{O} \\
\mathrm{H}^{\bullet}+\mathrm{O}_{2} & \longrightarrow \mathrm{HO}_{2} \\
2 \mathrm{OH}^{\bullet} & \longrightarrow \mathrm{H}_{2} \mathrm{O}_{2} \\
\mathrm{OOH}^{\bullet} & \longrightarrow \mathrm{H}_{2} \mathrm{O}_{2}+\mathrm{O}_{2}
\end{aligned}
$$

Also, hydroxyl radicals are generated as shown by the following reaction:

$$
\left.\left.\left.\mathrm{H}_{2} \mathrm{O}_{2}+\right)\right)\right) \longrightarrow 2 \mathrm{OH}^{\bullet}
$$

Thus, the combination of heterogeneous Fenton process with the ultrasound and UV light irradiation will increase the 
hydroxyl radical production which will make the treatment process more efficient.

\section{Material and Methods}

2.1. Chemicals and Materials. The acid green 50 dye (AG50) was provided by the local textile industry. Hydrogen peroxide $(30 \% \mathrm{w} / \mathrm{w})$, ferrous sulfate, sulfuric acid, sodium hydroxide, and hydrated ferric chloride solutions were purchased from Sigma-Aldrich. All reagents were of analytical grade and were used without further purification. Total iron determination analyses were carried out using standard reagents and standard methods [32]. Soft drink empty cans were used as source of aluminum foil which was used after sulfuric acid treatment [33].

2.2. Catalyst Preparation. Catalyst preparation followed the procedure reported elsewhere [13]. Briefly, it consisted of dissolving $1 \mathrm{~g}$ of aluminum can bits in $50 \mathrm{~mL}$ of sodium hydroxide solution $\left(4 \mathrm{~mol} \mathrm{~L}^{-1}\right)$ followed by filtration. The filtered solution was mixed with $50 \mathrm{~mL}$ of different $\mathrm{Fe}^{3+}$ concentrations in acidic solutions of ferric chloride used as precursor salt under stirring. This step neutralized the solution and formed a brownish aluminum hydroxide gel impregnated with iron. The product was filtered, washed with distilled water repeatedly to remove $\mathrm{Na}^{+}, \mathrm{Cl}^{-}$, and $\mathrm{SO}_{4}{ }^{2-}$ ions, dried in an oven at $105^{\circ} \mathrm{C}$ for $12 \mathrm{~h}$, and ground to powder using an agate mortar. The powders were subjected to calcination at different temperatures for $6 \mathrm{~h}$ under air atmosphere.

2.3. Procedure. All degradation tests were performed in a batch recirculation sonophotoreactor $(250 \mathrm{~mL})$ to investigate the effects of sonolysis (Us), photolysis (UV light), Fenton process, and Fenton process combined with Us and UV irradiation on dye degradation using the immobilized catalyst. An ultrasound probe (21 $\mathrm{mm}$ diameter) was dipped into a cooling jacketed stainless steel cell powered by an ultrasonic processor of $20 \mathrm{kHz}$ ( $60 \%$ amplitude, 0.5 cycles, Dr. Hielscher). The experimental temperature of the sonophotoreactor was kept within $27^{\circ} \mathrm{C} \pm 3^{\circ} \mathrm{C}$. A $15 \mathrm{~W}$ UV lamp (cut-off wavelength $352 \mathrm{~nm}, 41 \mathrm{~cm}$ long with $3 \mathrm{~cm}$ diameter, Cole Parmer) hosted in a Pyrex jacket illuminated the cylindrical photoreactor. Each experiment was carried out using $100 \mathrm{mg} \mathrm{L}^{-1}$ of $\mathrm{Fe}_{2} \mathrm{O}_{3}$ catalyst supported on $\mathrm{Al}_{2} \mathrm{O}_{3}$ (with three different iron contents calcined at $500^{\circ} \mathrm{C}$ and a fix iron load calcined at different temperatures) in a solution containing the desired dye concentration together with the stoichiometric amount of $\mathrm{H}_{2} \mathrm{O}_{2}$ at the $\mathrm{pH}$ under test $(2,3$, 5 , and 7). Samples were withdrawn at timed intervals and immediately the absorbance and total organic carbon (TOC) were measured to follow the instantaneous oxidation. Dye concentration was known from a calibration curve using the absorbance of the samples. It is worth mentioning that, by only measuring the wavelength of maximum absorption, there is potential interference of the transformation intermediates that could exhibit absorbtion at the same wavelength as the dye. By doing so, one gets a lower limit for degradation since the dye may be degraded faster.

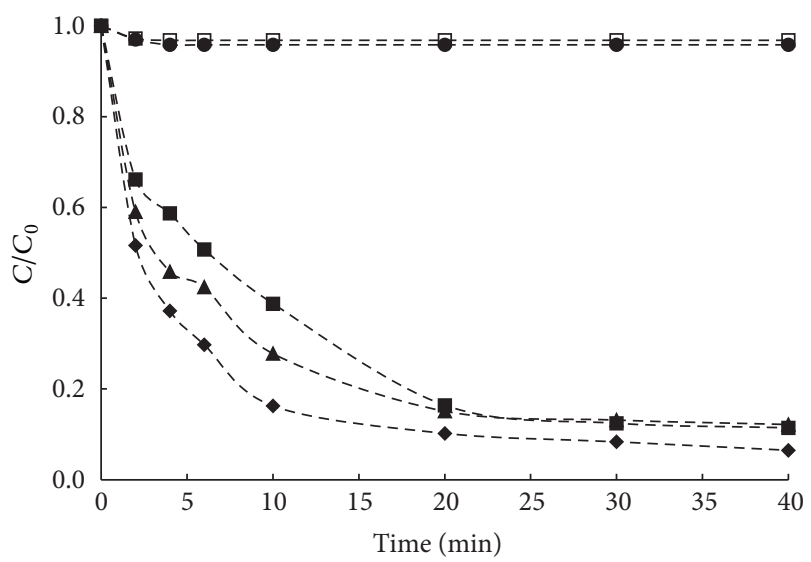

Figure 1: Degradation of $4 \times 10^{-5} \mathrm{~mol} \mathrm{~L}^{-1}$ AG50 by the Fenton process using $2.85 \times 10^{-3} \mathrm{~mol} \mathrm{~L}^{-1} \mathrm{H}_{2} \mathrm{O}_{2}$ with different iron content $\left(\mathrm{mg} / \mathrm{g} \mathrm{Fe}_{2} \mathrm{O}_{3}\right)$ in $100 \mathrm{mg} \mathrm{L}^{-1}$ of catalyst calcined at $500^{\circ} \mathrm{C}($ at $\mathrm{pH}=2)$. $(\bullet) 0.0,(\square) 14.4,(\Delta) 18.1,(\diamond) 37.4$, and () 0.0 without $\mathrm{H}_{2} \mathrm{O}_{2}$.

\section{Results and Discussion}

3.1. Catalyst Content on Supporting Material. Figure 1 shows the discoloration of AG50 $\left(4 \times 10^{-5} \mathrm{~mol} \mathrm{~L}^{-1}\right)$ over $100 \mathrm{mg} \mathrm{L}^{-1}$ of catalysts annealed at $500^{\circ} \mathrm{C}$ with different iron contents at $\mathrm{pH} 2$ by the Fenton process using $\mathrm{Fe}_{2} \mathrm{O}_{3}$ catalyst; this figure also includes two control experiments: $(\bullet) \mathrm{H}_{2} \mathrm{O}_{2}$ at stoichiometry $\left(2.85 \times 10^{-3} \mathrm{~mol} \mathrm{~L}^{-1}\right)$ and $(\square)$ absence of $\mathrm{H}_{2} \mathrm{O}_{2}$. Initially, faster discoloration up to $20 \mathrm{~min}$ is observed as the iron content on the supporting material increases. Then, no further discoloration is obtained. Negligible discoloration is attained either with $\mathrm{H}_{2} \mathrm{O}_{2}$ at stoichiometry or in the absence of $\mathrm{H}_{2} \mathrm{O}_{2}$. Figure 2 shows the TOC removal of AG50 $(4 \times$ $10^{-5} \mathrm{~mol} \mathrm{~L}^{-1}$ ) at $40 \mathrm{~min}$ reaction time as a function of different iron contents during the Fenton reaction (Figure 2(a)) and its combinations (Figure 2(b)) with UV light and ultrasound (Us), using $100 \mathrm{mg} \mathrm{L}^{-1}$ of catalyst annealed at $500^{\circ} \mathrm{C}$ at $\mathrm{pH}$ 2. The two higher iron concentrations report similar TOC abatement in the Fenton process $(\mathrm{F})$. The Fenton process combined with Us and UV light $(\mathrm{F}+\mathrm{UV}+\mathrm{Us})$ in the presence of $14.4 \mathrm{mg}$ of iron/g shows the highest mineralization of the pollutant. Clearly, the combination of these processes enhances dye degradation compared to the Fenton process when the lower iron content is used. The enhancement of discoloration and TOC abatement is attributed to the generation of radicals such as ${ }^{\circ} \mathrm{OH}$ and $\mathrm{OOH}^{*}$ by the catalytic decomposition of hydrogen peroxide by the iron present in the solid catalysts.

The effect of processes such as adsorption, UV light, and ultrasonic irradiation on the discoloration efficiency is reported in Figure 3. This figure also presents the performance of Fenton reaction (F) combined with ultrasound ( $F+$ Us), UV irradiation $(\mathrm{F}+\mathrm{UV})$, and $\mathrm{F}+\mathrm{UV}+\mathrm{Us}$ using $100 \mathrm{mg} \mathrm{L}^{-1}$ of solid catalyst $\left(37.4 \mathrm{mg} / \mathrm{g} \mathrm{Fe}_{2} \mathrm{O}_{3}\right)$ at $\mathrm{pH}$ 2. The ultrasonic irradiation achieved $48 \%$ discoloration efficiency, $19 \%$ adsorption, and only $10 \% \mathrm{UV}$ irradiation at $40 \mathrm{~min}$ reaction time; in contrast, a colorless solution was obtained at $40 \mathrm{~min}$ by the Fenton reaction in tandem with UV + Us. 


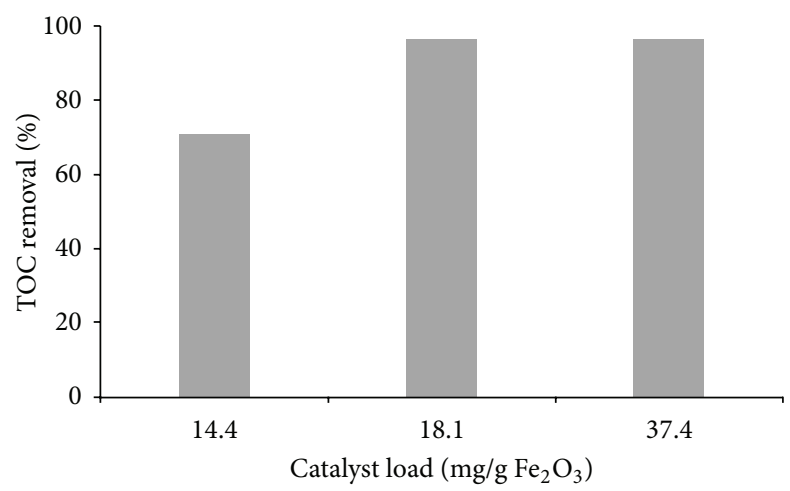

(a)

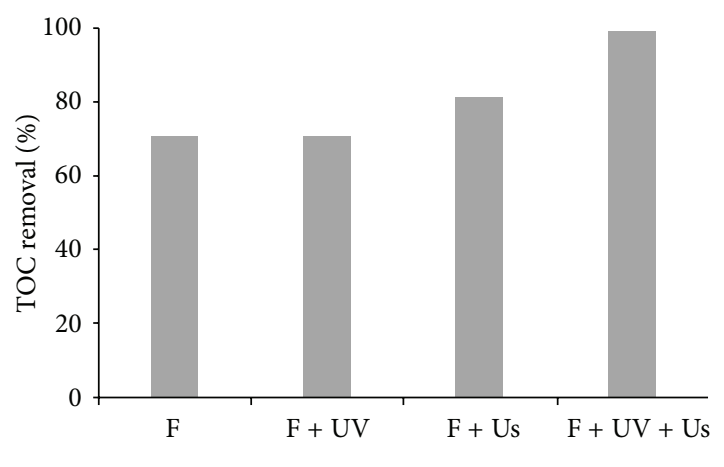

(b)

FIGURE 2: TOC removal of AG50 at 40 min reaction time as a function of different iron contents during the Fenton process (F) (a) and its combinations (b) with UV light and ultrasound (Us), using $100 \mathrm{mg} \mathrm{L}^{-1}$ of catalyst (with $14.4 \mathrm{mg}$ of iron/g catalyst).

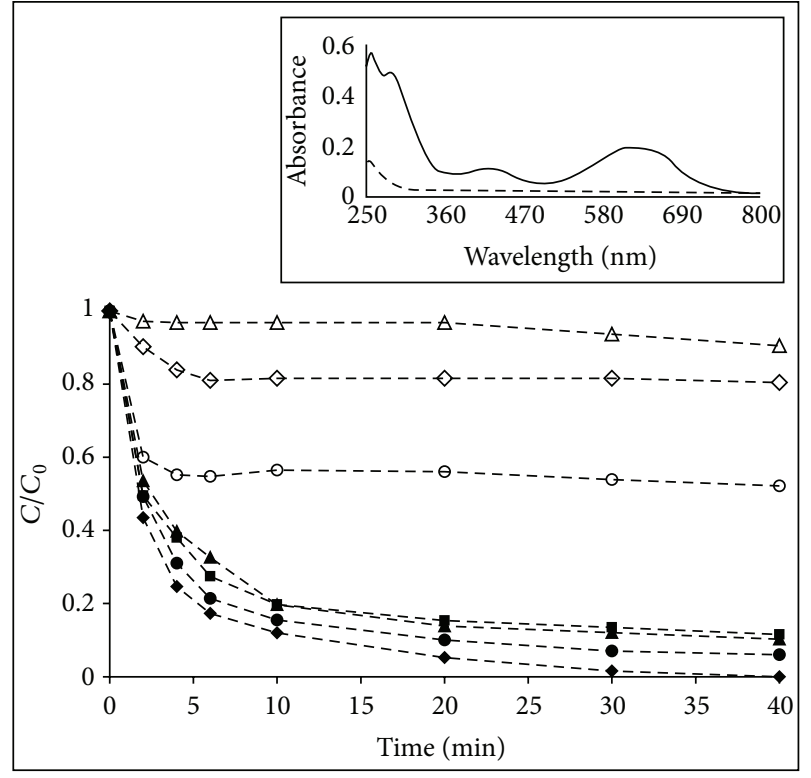

FIGURE 3: Normalized color removal of AG50 $\left(4 \times 10^{-5} \mathrm{~mol} \mathrm{~L}^{-1}\right)$ at $\mathrm{pH} 2$ with $37.4 \mathrm{mg} / \mathrm{g}$ catalyst annealed at $500^{\circ} \mathrm{C}$ using $100 \mathrm{mg} \mathrm{L}^{-1}$ of catalyst load by different processes: $(\diamond)$ adsorption, $(\triangle)$ UV light only, (O) Us only, (ム) Fenton reaction (F), (₫) F + UV light (UV), $(\bullet) \mathrm{F}+$ ultrasound $(\mathrm{Us})$, and $(\diamond) \mathrm{F}+\mathrm{UV}+\mathrm{Us}$. The insert shows the absorbance spectra during dye degradation: initial (continuous line) and final at $40 \mathrm{~min}$ (dashed line) in the F + UV + Us.

When Fenton process is combined with ultrasound and UV light irradiation, $94 \%$ and $85 \%$ discoloration efficiency are achieved, respectively. The insert of Figure 3 depicts the initial (continuous line) and final (at $30 \mathrm{~min}$, dashed line) absorbance spectra during dye degradation by $\mathrm{F}+\mathrm{UV}+\mathrm{Us}$. This finding suggests a structural change of the AG50 textile dye.

These results indicate that when the Fenton process, using solid iron catalyst, is combined with ultrasound and UV light irradiation, the discoloration efficiencies are higher than that obtained by the Fenton process alone. The effect of the

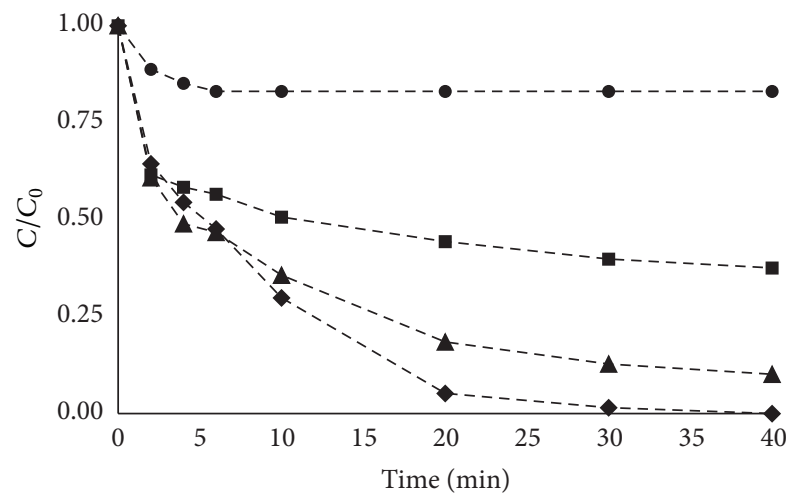

FIGURE 4: Normalized concentration profile as a function of $\mathrm{pH}$ from acid green $50\left(4 \times 10^{-5} \mathrm{~mol} \mathrm{~L}^{-1}\right)$ solutions by Fenton process, using $37.4 \mathrm{mg} / \mathrm{g} \mathrm{Fe}_{2} \mathrm{O}_{3}$ catalyst, combined with UV and Us irradiation (catalyst annealed at $500^{\circ} \mathrm{C}$ ). $\diamond \mathrm{pH} 2, \boldsymbol{\Delta} \mathrm{pH} 3, \boldsymbol{\sim p H} 5$, and $\bullet \mathrm{pH}$ 7.

ultrasonic irradiation is attributed to (a) transient cavitation that increases the mass transfer of the substrates to the catalyst surface $[34,35]$, (b) additional production of reactive species such as $\mathrm{OH}^{*}$ radicals according to reactions (12) and (17), and (c) the acoustic cavitation that also contributes to the increase in the activity of the catalyst surface area due to the continuous cleaning and chemical activation of the catalyst surface. Thus, more reactant surface area is readily formed for further surface reactions [36].

3.2. $\mathrm{pH}$ of the Aqueous Solution. The $\mathrm{pH}$ in the aqueous system is an important parameter since it affects the catalytic performance and the stability of the catalysts $\left(\mathrm{Fe}_{2} \mathrm{O}_{3}\right)$. The influence of the initial $\mathrm{pH}$ on the degradation of AG50 dye using $37.4 \mathrm{mg} / \mathrm{g} \mathrm{Fe}_{2} \mathrm{O}_{3}$ catalyst by the Fenton reaction combined with UV and Us irradiation is depicted in Figure 4. This figure shows that the discoloration rate increases as the $\mathrm{pH}$ decreases and reaches an optimum at initial $\mathrm{pH}=2.0$. At the initial $\mathrm{pH}$ of 2.0, a colorless solution is observed at $40 \mathrm{~min}$; at $\mathrm{pH} 3.0,90 \%$ of the dye is converted at $40 \mathrm{~min}$ reaction time; at $\mathrm{pH}$ 5.0, 62\%; and at $\mathrm{pH} 7.0,17 \%$. One of the drawbacks of 


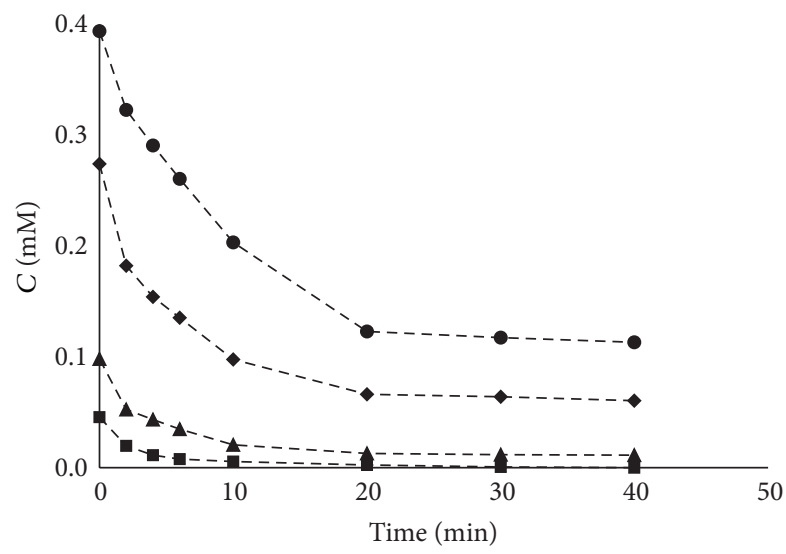

FIGURE 5: AG50 dye degradation varying the initial concentration of the dye by the Fenton process using $37.4 \mathrm{mg} / \mathrm{g} \mathrm{Fe} \mathrm{O}_{3}$ catalyst in tandem with UV light and ultrasonic irradiation using $\mathrm{H}_{2} \mathrm{O}_{2}$ in stoichiometric amounts. $(\bullet) 0.39 \mathrm{mmol} \mathrm{L}^{-1},(\diamond) 0.27 \mathrm{mmol} \mathrm{L}^{-1},(\mathbf{\Delta})$ $9.8 \times 10^{-2} \mathrm{mmol} \mathrm{L}^{-1}$, and (ロ) $4.6 \times 10^{-2} \mathrm{mmol} \mathrm{L}^{-1}$.

the Fenton reaction is the useful $\mathrm{pH}$ range (2.5-4.0 [5]). The oxidation potential of ${ }^{\circ} \mathrm{OH}$ is lower at $\mathrm{pH} 5.0$ and $\mathrm{pH} 7.0$ than that at $\mathrm{pH} 2$ and $\mathrm{pH} 3$. At $\mathrm{pH}>3$, the formation of hydroxyl radicals slows down because of hydrolysis of $\mathrm{Fe}(\mathrm{III})$ and $\mathrm{Fe}^{3+}$ precipitation as $\mathrm{Fe}(\mathrm{OH})_{3}$ from the solution. Thus, the efficiency of Fenton oxidation decreases at $\mathrm{pH}$ higher than 3. Also, ferric hydroxide formation could decompose $\mathrm{H}_{2} \mathrm{O}_{2}$ into $\mathrm{O}_{2}$ and $\mathrm{H}_{2} \mathrm{O}$, and consequently the oxidation rate is decreased as a result of the low concentration of hydroxyl radicals [37]. Similar performance in the oxidation of dye solutions using iron-alumina catalyst in the heterogeneous Fenton process was reported $[14,15]$. A detrimental effect on decoloration at $\mathrm{pH}>3$ was found; thus, based on these studies, the aluminabased iron catalysts exhibit higher degradation efficiency in acidic $\mathrm{pH}$.

3.3. Influence of Initial Dye Concentration. Figure 5 presents the AG50 dye degradation varying the initial concentration of the dye from $4.6 \times 10^{-5}$ to $39.4 \times 10^{-5} \mathrm{~mol} \mathrm{~L}^{-1}$ (27 to $227 \mathrm{mg} \mathrm{L}^{-1}$ ) by the Fenton process in tandem with UV light and ultrasonic irradiation. As can be observed in this figure, the discoloration efficiency decreases as the initial dye concentration increases. This can be explained on the basis that higher initial concentrations of $\mathrm{H}_{2} \mathrm{O}_{2}$ are required to degrade higher dye concentrations [13]. Thus, the high amount of $\mathrm{H}_{2} \mathrm{O}_{2}$ may react with ${ }^{\circ} \mathrm{OH}$ radicals generating $\mathrm{H}_{2} \mathrm{O}$ and the less oxidative $\mathrm{HO}_{2}{ }^{\circ}$ radicals (see (18)). Another feasible explanation to this phenomenon is that the number of active sites available was decreased by the dye molecules because of their competitive adsorption on the catalyst surface [38]:

$$
\mathrm{H}_{2} \mathrm{O}_{2}+\mathrm{OH}^{\bullet} \longrightarrow \mathrm{H}_{2} \mathrm{O}+\mathrm{HO}_{2} \cdot
$$

3.4. Influence of Annealing Temperature. The performance of the catalyst on color removal is slightly influenced by the thermal treatment and particularly by the catalyst calcination temperature adopted, regardless of the treatment process, as

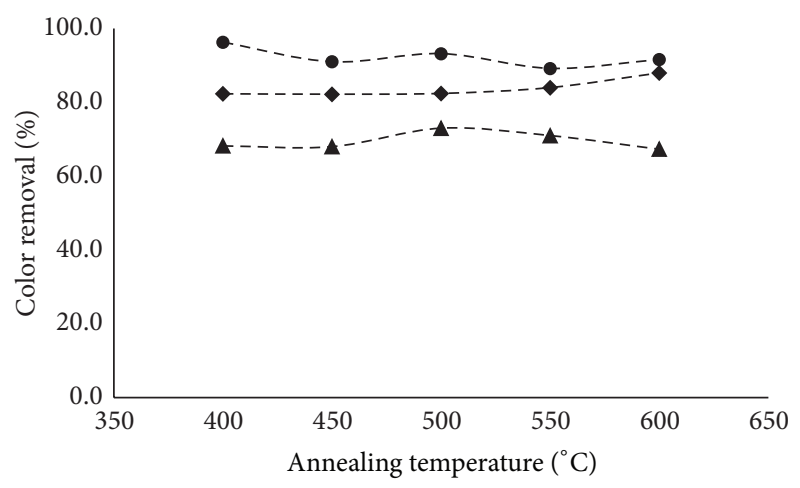

FIGURE 6: Influence of catalyst thermal treatment on AG50 degradation at $40 \mathrm{~min}$ reaction and $\mathrm{pH} 2$ using $100 \mathrm{mg} \mathrm{L}^{-1}$ of catalyst containing $37.4 \mathrm{mg} / \mathrm{g} \mathrm{Fe}_{2} \mathrm{O}_{3}:(\boldsymbol{\Delta}) \mathrm{F},(\bullet)$ F-Us, and $(\bullet)$ F-Us-UV.

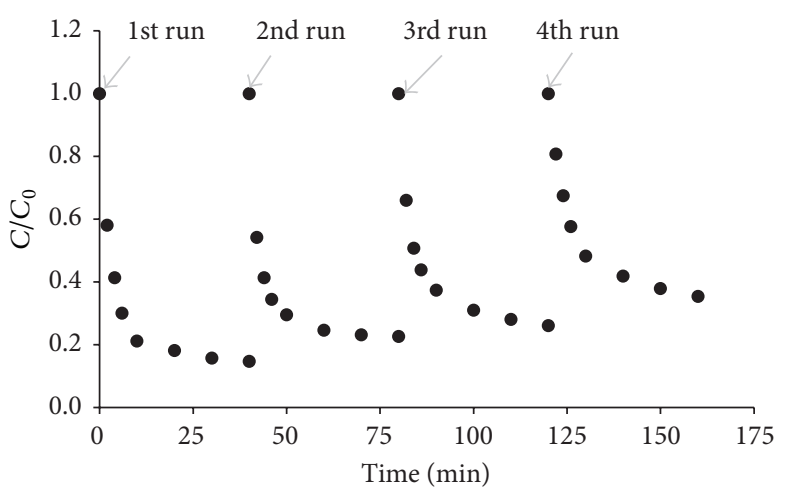

FIgURE 7: Catalyst reusability during four cycles using $100 \mathrm{mg} \mathrm{L}^{-1}$ of $37.4 \mathrm{mg} / \mathrm{g} \mathrm{Fe} \mathrm{O}_{3}$ catalyst calcined at $500^{\circ} \mathrm{C}$.

shown in Figure 6. The combination of the three processes (FUs-UV) yields better color removal at all catalyst annealing temperatures, followed by F-Us and F.

3.5. Catalyst Stability and Reusability. The reusability and stability of the active phase after successive recycling for four times during the Fenton process are shown in Figure 7. It is observed that the discoloration efficiencies decrease after each successive cycle $(85,77,74$, and $65 \%$, resp.) which may be attributed to iron leaching. Indeed, $0.55 \mathrm{mg} \mathrm{L}^{-1}$ of iron was lixiviated at the end of the fourth cycle; this represents the $15 \%$ of iron leached from the catalyst at $2.7 \mathrm{~h}$ of catalyst reuse. Thus, the active phase exhibits good activity and reusability up to three successive cycles. The leaching of iron may be important because excessive concentrations of dissolved iron in the effluent would need an elimination step. Apart from catalyst reuse, typical levels of leached iron during normal operation should be reported.

\section{Conclusions}

These results demonstrate that the performance of the Fenton reaction catalyzed by $\mathrm{Fe}_{2} \mathrm{O}_{3}$ is improved by its combination with UV light and ultrasonic irradiation, using low iron content on the catalyst which yields high discoloration 
and mineralization of AG50. Thus, such combination is a promising advanced oxidation technology for the treatment of wastewater containing AG50 textile dye. The $\mathrm{pH}$ of the solution is the parameter that influences more the performance of the catalyst compared to the rest of the parameters tested.

\section{Competing Interests}

The authors declare that they have no competing interests.

\section{Acknowledgments}

The authors would like to thank CONACYT for the grant given to Karen E. Barrera-Salgado.

\section{References}

[1] P. A. Carneiro, G. A. Umbuzeiro, D. P. Oliveira, and M. V. B. Zanoni, "Assessment of water contamination caused by a mutagenic textile effluent/dyehouse effluent bearing disperse dyes," Journal of Hazardous Materials, vol. 174, no. 1-3, pp. 694699, 2010.

[2] E. Castro, A. Avellaneda, and P. Marco, "Combination of advanced oxidation processes and biological treatment for the removal of benzidine-derived dyes," Environmental Progress \& Sustainable Energy, vol. 33, no. 3, pp. 873-885, 2014.

[3] M. Pérez, F. Torrades, X. Domènech, and J. Peral, "Fenton and photo-Fenton oxidation of textile effluents," Water Research, vol. 36, no. 11, pp. 2703-2710, 2002.

[4] J. J. Pignatello, "Dark and photoassisted $\mathrm{Fe}^{3+}$-catalyzed degradation of chlorophenoxy herbicides by hydrogen peroxide," Environmental Science and Technology, vol. 26, no. 5, pp. 944951, 1992.

[5] J. Barrault, J.-M. Tatibouët, and N. Papayannakos, "Catalytic wet peroxide oxidation of phenol over pillared clays containing iron or copper species," Comptes Rendus de l'Académie des SciencesSeries IIC: Chemistry, vol. 3, no. 10, pp. 777-783, 2000.

[6] S. Navalon, M. Alvaro, and H. Garcia, "Heterogeneous Fenton catalysts based on clays, silicas and zeolites," Applied Catalysis B: Environmental, vol. 99, no. 1-2, pp. 1-26, 2010.

[7] J. Chen and L. Zhu, "Heterogeneous UV-Fenton catalytic degradation of dyestuff in water with hydroxyl-Fe pillared bentonite," Catalysis Today, vol. 126, no. 3-4, pp. 463-470, 2007.

[8] E. G. Garrido-Ramírez, B. K. G. Theng, and M. L. Mora, "Clays and oxide minerals as catalysts and nanocatalysts in Fenton-like reactions-a review," Applied Clay Science, vol. 47, no. 3-4, pp. 182-192, 2010.

[9] Y. Wang, Y. Gao, L. Chen, and H. Zhang, "Goethite as an efficient heterogeneous Fenton catalyst for the degradation of methyl orange," Catalysis Today, vol. 252, pp. 107-112, 2015.

[10] Q. Wang, S. Tian, J. Long, and P. Ning, "Use of Fe(II)Fe(III)LDHs prepared by co-precipitation method in a heterogeneousFenton process for degradation of Methylene Blue," Catalysis Today, vol. 224, pp. 41-48, 2014.

[11] J. A. Zazo, J. Bedia, C. M. Fierro, G. Pliego, J. A. Casas, and J. J. Rodriguez, "Highly stable Fe on activated carbon catalysts for CWPO upon $\mathrm{FeCl}_{3}$ activation of lignin from black liquors," Catalysis Today, vol. 187, no. 1, pp. 115-121, 2012.
[12] Y. Wang, H. Zhao, and G. Zhao, "Iron-copper bimetallic nanoparticles embedded within ordered mesoporous carbon as effective and stable heterogeneous Fenton catalyst for the degradation of organic contaminants," Applied Catalysis B: Environmental, vol. 164, pp. 396-406, 2015.

[13] C. Ramos-Preza, S. Silva-Martínez, A. Álvarez-Gallegos, J. Vergara-Sánchez, C. Pineda-Arellano, and R. Rodríguez-Díaz, "Mineralization of Acid Green 50 by $\mathrm{Fe}_{2} \mathrm{O}_{3}-\mathrm{Al}_{2} \mathrm{O}_{3}$ as a highly active hetero-Fenton catalyst," Desalination and Water Treatment, vol. 52, no. 19-21, pp. 3526-3524, 2014.

[14] I. Muthuvel and M. Swaminathan, "Photoassisted Fenton mineralisation of Acid Violet 7 by heterogeneous $\mathrm{Fe}(\mathrm{III})-\mathrm{Al}_{2} \mathrm{O}_{3}$ catalyst," Catalysis Communications, vol. 8, no. 7, pp. 981-986, 2007.

[15] B. Muthukumari, K. Selvam, I. Muthuvel, and M. Swaminathan, "Photoassisted hetero-Fenton mineralisation of azo dyes by $\mathrm{Fe}(\mathrm{II})-\mathrm{Al}_{2} \mathrm{O}_{3}$ catalyst," Chemical Engineering Journal, vol. 153, no. 1-3, pp. 9-15, 2009.

[16] M. Hartmann, S. Kullmann, and H. Keller, "Wastewater treatment with heterogeneous Fenton-type catalysts based on porous materials," Journal of Materials Chemistry, vol. 20, no. 41, pp. 9002-9017, 2010.

[17] I. Muthuvel, B. Krishnakumar, and M. Swaminathan, "Solar active fire clay based hetero-Fenton catalyst over a wide $\mathrm{pH}$ range for degradation of Acid Violet 7," Journal of Environmental Sciences, vol. 24, no. 3, pp. 529-535, 2012.

[18] Y. Dong, W. Dong, Y. Cao, Z. Han, and Z. Ding, "Preparation and catalytic activity of $\mathrm{Fe}$ alginate gel beads for oxidative degradation of azo dyes under visible light irradiation," Catalysis Today, vol. 175, no. 1, pp. 346-355, 2011.

[19] M. Bayat, M. Sohrabi, and S. J. Royaee, "Degradation of phenol by heterogeneous Fenton reaction using Fe/clinoptilolite," Journal of Industrial and Engineering Chemistry, vol. 18, no. 3, pp. 957-962, 2012.

[20] J. K. Kim, F. Martinez, and I. S. Metcalfe, "The beneficial role of use of ultrasound in heterogeneous Fenton-like system over supported copper catalysts for degradation of p-chlorophenol," Catalysis Today, vol. 124, no. 3-4, pp. 224-231, 2007.

[21] K. A. Sashkina, V. S. Labko, N. A. Rudina, V. N. Parmon, and E. V. Parkhomchuk, "Hierarchical zeolite FeZSM-5 as a heterogeneous Fenton-type catalyst," Journal of Catalysis, vol. 299, pp. 44-52, 2013.

[22] E. Basturk and M. Karatas, "Advanced oxidation of Reactive Blue 181 solution: a comparison," Ultrasonics Sonochemistry, vol. 21, no. 5, pp. 1881-1885, 2014.

[23] P. R. Gogate and A. B. Pandit, "A review of imperative technologies for wastewater treatment II: hybrid methods," Advances in Environmental Research, vol. 8, no. 3-4, pp. 553-597, 2004.

[24] M. V. Bagal and P. R. Gogate, "Wastewater treatment using hybrid treatment schemes based on cavitation and Fenton chemistry: a review," Ultrasonics Sonochemistry, vol. 21, no. 1, pp. 1-14, 2014.

[25] X. Zhong, S. Royer, H. Zhang et al., "Mesoporous silica irondoped as stable and efficient heterogeneous catalyst for the degradation of C.I. Acid Orange 7 using sono-photo-Fenton process," Separation and Purification Technology, vol. 80, no. 1, pp. 163-171, 2011.

[26] M. Zarei, A. R. Khataee, R. Ordikhani-Seyedlar, and M. Fathinia, "Photoelectro-Fenton combined with photocatalytic process for degradation of an azo dye using supported $\mathrm{TiO}_{2}$ nanoparticles and carbon nanotube cathode: neural network 
modeling," Electrochimica Acta, vol. 55, no. 24, pp. 7259-7265, 2010.

[27] S. S. Abu Amr and H. A. Aziz, "New treatment of stabilized leachate by ozone/Fenton in the advanced oxidation process," Waste Management, vol. 32, no. 9, pp. 1693-1698, 2012.

[28] J. J. Pignatello, E. Oliveros, and A. MacKay, "Advanced oxidation processes for organic contaminant destruction based on the Fenton reaction and related chemistry," Critical Reviews in Environmental Science and Technology, vol. 36, no. 1, pp. 1-84, 2006.

[29] M. L. Kremer, "Mechanism of the Fenton reaction. Evidence for a new intermediate," Physical Chemistry Chemical Physics, vol. 1, no. 15, pp. 3595-3605, 1999.

[30] T. L. P. Dantas, V. P. Mendonça, H. J. José, A. E. Rodrigues, and R. F. P. M. Moreira, "Treatment of textile wastewater by heterogeneous Fenton process using a new composite $\mathrm{Fe}_{2} \mathrm{O}_{3}$ /carbon," Chemical Engineering Journal, vol. 118, no. 1-2, pp. 77-82, 2006.

[31] M. Tokumura, R. Morito, R. Hatayama, and Y. Kawase, "Iron redox cycling in hydroxyl radical generation during the photoFenton oxidative degradation: dynamic change of hydroxyl radical concentration," Applied Catalysis B: Environmental, vol. 106, no. 3-4, pp. 565-576, 2011.

[32] Hach Company, Water Analysis Handbook, Hach Company, Loveland, Colo, USA, 1992.

[33] S. S. Martínez, L. Albañil Sánchez, A. A. Álvarez Gallegos, and P. J. Sebastian, "Coupling a PEM fuel cell and the hydrogen generation from aluminum waste cans," International Journal of Hydrogen Energy, vol. 32, no. 15, pp. 3159-3162, 2007.

[34] P. R. Birkin and S. Silva-Martinez, "The effect of ultrasound on mass transport to a microelectrode," Journal of the Chemical Society, Chemical Communications, no. 17, pp. 1807-1808, 1995.

[35] P. R. Birkin and S. Silva-Martinez, "A study of the effect of ultrasound on mass transport to a microelectrode," Journal of Electroanalytical Chemistry, vol. 416, no. 1-2, pp. 127-138, 1996.

[36] H. Zhang, H. Gao, C. Cai, C. Zhang, and L. Chen, "Decolorization of Crystal Violet by ultrasound/ heterogeneous Fenton process," Water Science and Technology, vol. 68, no. 11, pp. 25152520, 2013.

[37] H. Selçuk, G. Eremektar, and S. Meriç, "The effect of pre-ozone oxidation on acute toxicity and inert soluble COD fractions of a textile finishing industry wastewater," Journal of Hazardous Materials, vol. 137, no. 1, pp. 254-260, 2006.

[38] S. Azabou, W. Najjar, A. Gargoubi, A. Ghorbel, and S. Sayadi, "Catalytic wet peroxide photo-oxidation of phenolic olive oil mill wastewater contaminants: part II. Degradation and detoxification of low-molecular mass phenolic compounds in model and real effluent," Applied Catalysis B: Environmental, vol. 77, no. 1-2, pp. 166-174, 2007. 

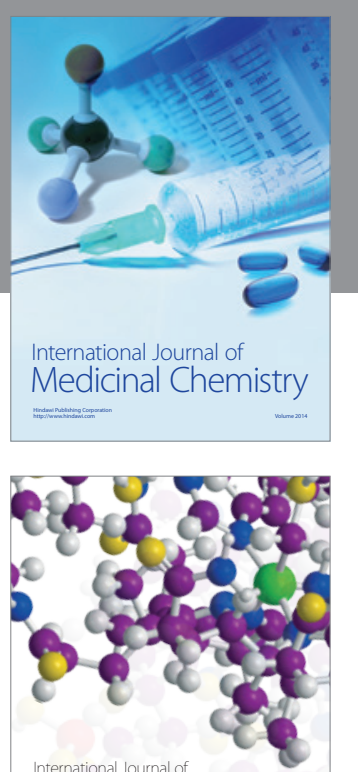

Carbohydrate Chemistry

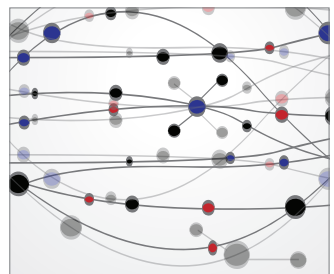

The Scientific World Journal
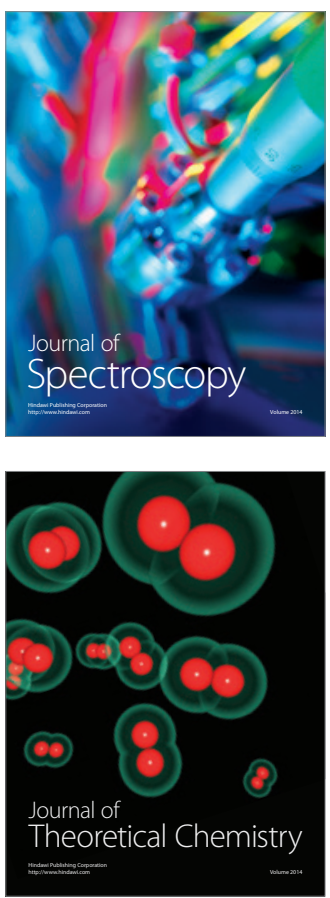
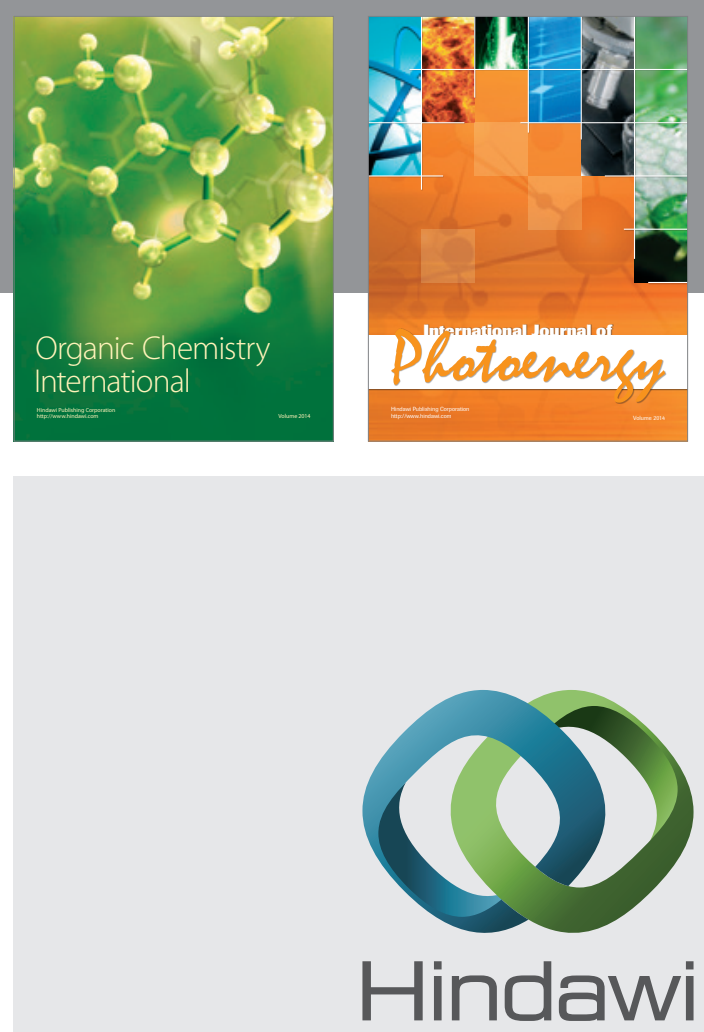

Submit your manuscripts at

http://www.hindawi.com

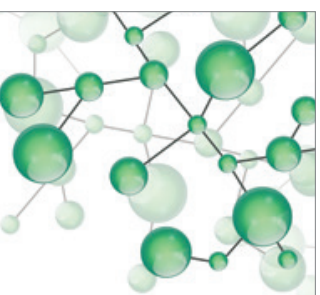

International Journal of

Inorganic Chemistry

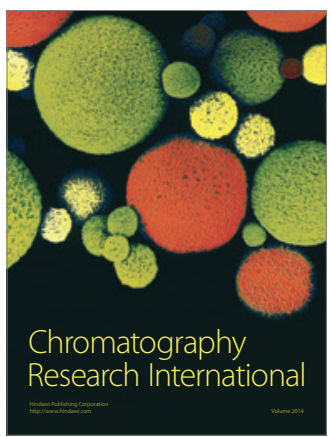

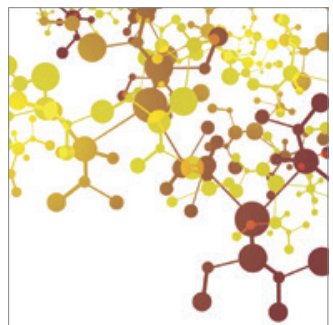

Applied Chemistry
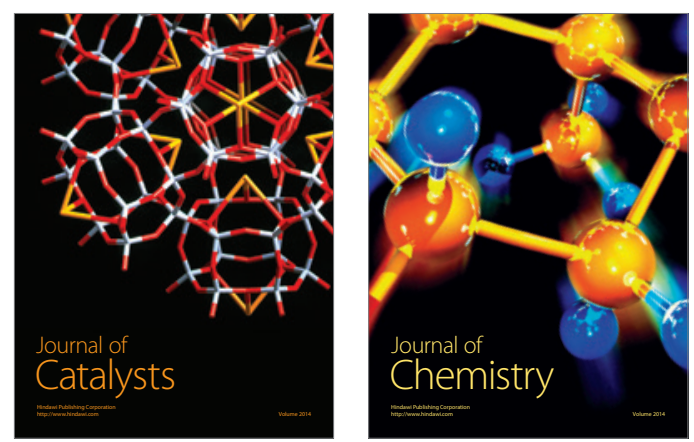
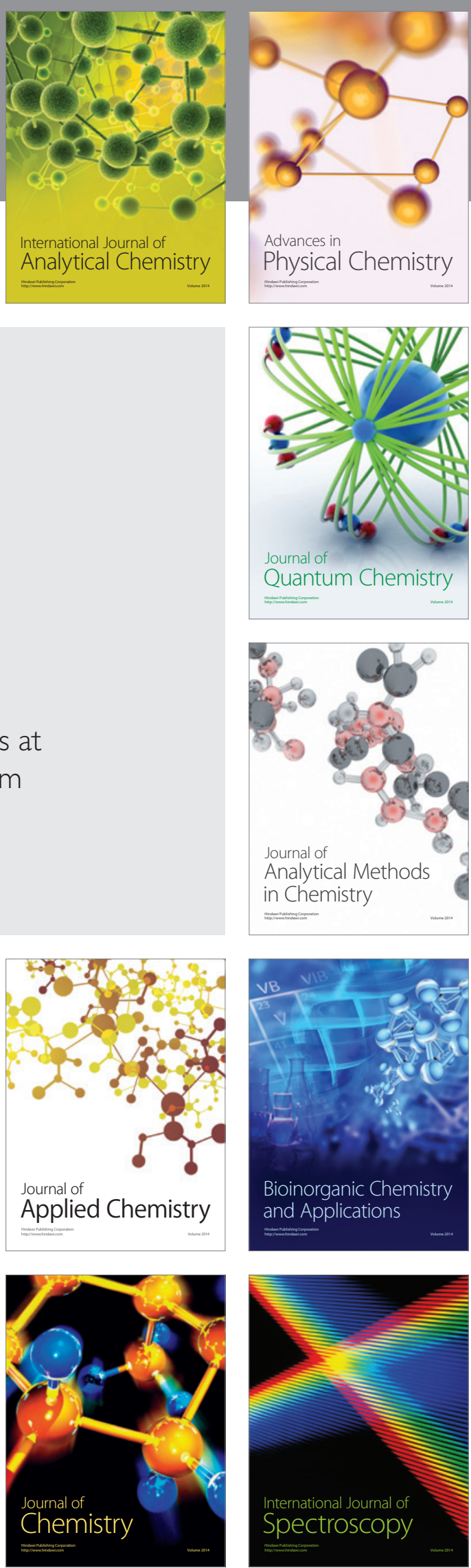